\title{
Syzygium Samarangense: Review of Phytochemical Compounds and Pharmacological Activities
}

\author{
Chrisanta Tarigan ${ }^{1, *(D)}$, Hegar Pramastya ${ }^{1(D)}$, Muhamad Insanu ${ }^{1}$, , Irda Fidrianny ${ }^{1}$ (D) \\ 1 Department of Pharmaceutical Biology, School of Pharmacy, Bandung Institute of Technology, Bandung, Indonesia \\ * Correspondence: chrisantarigan@gmail.com (C.T.);
}

Received: 27.04.2021; Revised: 1.06.2021; Accepted: 5.06.2021; Published: 18.06.2021

\begin{abstract}
Jambu semarang (Syzygium samarangense), which belongs to Myrtaceae family, is widely cultivated in Asia and the Pacific region. This review systematically described the scientifically proven information about the plant's phytochemical contents, traditional usage, and pharmacological activities. Elucidated primary and secondary metabolites of S. samarangense mostly belong to flavonoids, phenolic compounds, resorcinol derivatives, acylphloroglucinols, tannins, terpenoids, and sterols. Various parts of the plant have been used traditionally to remedy cold, itches, cracked tongue, dysentery, and diabetes. It is also commonly consumed fresh or processed as wines, jams, nata, vinegar, and jellies. Currently, in vitro and in vivo experiments of the plant extract have demonstrated various pharmacological activities such as antioxidant, antimicrobial, anti-HIV, analgesic, anti-inflammatory, antihyperglycemic, antidiabetic, thrombolytic, spasmolytic, cytotoxic, hepatoprotective, anticancer, anthelmintic, anxiolytic, protease inhibitory, and immunomodulatory effect. Further research in standardization and clinical studies is highly expected for future development.
\end{abstract}

Keywords: Syzygium samarangense; jambu semarang; phytochemical compounds; traditional uses; pharmacological activities; toxicology.

(C) 2021 by the authors. This article is an open-access article distributed under the terms and conditions of the Creative Commons Attribution (CC BY) license (https://creativecommons.org/licenses/by/4.0/).

\section{Introduction}

Natural products still contribute to drug developments nowadays, where up to $50 \%$ of approved drugs in the last 30 years isolated from natural products [1]. Natural products are well known to be used as food or spice, but some of them also have a significant effect as medicines [2]. Myrtaceae, in which the genus of Syzygium is placed, is one of the largest plant families that consists of 3,800-5,800 species in 140 genera [3]. Meanwhile, Syzygium is the largest woody genus of flowering plants and the $16^{\text {th }}$ most diverse genus with $1,100-1,200$ species widely spread in the tropical and subtropical regions of the world [4]. There are several metabolites commonly produced by the Syzygium genus, such as terpenoids sysamarins A-G), chalcones, (-)-epigallocatechin, samarangensis A-B, pinocembrin, samarone A-D, jasmonic acid, lignans, alkyl phloroglucinols, hydrolyzable tannins, and other derivates [3].

Syzygium samarangense is a native plant of Andaman and Solomon Island cultivated in Asia and the Pacific region, especially in Indonesia [2,5]. This plant is generally known as jambu semarang, java apple, java rose apple, mountain apple, samarang rose apple, wax jambu, wax apple, jamrul, malay apple, chompu-khieo, or makopa [6-8]. In Chinese, it is called jin shan pu tao, lián wù, lián-bū nan yang pu tao, yang pu tao [8]. Fruit of jambu semarang can be harvested at least three times a year [9]. The fruits are primarily consumed fresh, but they are 
also made into wines, sauces, jams, desserts, liquors, vinegar, and jellies in a small percentage $[9,10]$.

The evergreen tree of known to grow well in the land with a sea level above 1,200 $\mathrm{m}$ during a long dry season up to a height of 3-15 m with near ground branches. It can be propagated by cutting, grafting, seeding, and air-layering. Its leaves are opposite, oblong to elliptic shape, with a size of 6-30 cm length and $4-15 \mathrm{~cm}$ width [11], colored in dark green to yellowish, and consist of the thick petiole. Flower parts of jambu semarang usually consist of $3,9,15$, or more flowers and can be found at the tip of the leaves, branches, or twigs. The stalk is estimated to have 3-5 mm length and $8-10 \mathrm{~mm}$ width size. Calyx of the flower has a yellow to green or white color with a semicircular form. The white corolla forms a round shape with a length estimated from 8-12 mm. Every flower contains 200-500 stamens approximately 3-4 $\mathrm{cm}$ long when the pistils only length around $4 \mathrm{~cm}$ with one $\mathrm{mm}$ diameter [11]. Its flowering period is in the early or late of the dry season and blooms a white to yellowish-white flower with a diameter of $2.5 \mathrm{~cm}$. After several months of the flowering period, the ripping period with follow-up [12].

A comparative study of internal transcribed spacer (ITS) and trnL-F (UAA and GAA) sequences, an efficient tool to identify gametophytes, shows that different growth places will give slightly different molecular and morphological characteristics due to its color, size, and shape of the fruits [13]. The fruit is a berry with fruit skin color splits from white to pale green and pink to pinkish-red. Its fruits have pear-like or bell-shaped with an oval-obovate shaped in a size of 3.5-5.5 $\mathrm{cm} \times 4.5-5.5 \mathrm{~cm}$ and crowned by the incurved lobes of fleshy calyx [9]. Some of the fruits were also examined as pseudo-stipe fruit [11]. The flesh is crisp, juicy, fresh, and fragrant with its sweet taste [12]. The skin of the fruit cannot be separated, so when it is cracked, the exocarp and mesocarp will be broken at the same time [14]. The fruit is commonly eaten after it is ripped [6] and only stored for up to a week in room conditions without preservatives [15].

Another molecular study summed the complete 159,109 bp long chloroplast genome, including 113 genes, of $S$. samarangense. The accession number of the genes is MH371141. Genome annotation of these full-length genes includes 79 protein-coding genes, 30 tRNA genes, and 4 rRNA genes. It was also known that their large single-copy (LSC), small singlecopy (SSC), and inverted repeats (IR) regions are 88,533; 18,882; and 25,847 bp long. This information was validated through comparison with 9 other various Myrtaceae species through a phylogenetic tree study, in which $S$. samarangense forms a clade similarity with the other family members with $100 \%$ bootstraps values [16].

Plant-based products are widely used from the early stage of human civilization to cure various diseases [17]. Syzygium genus is also used traditionally to tackle several diseases and disorders, such as hemorrhage, dysentery, gastrointestinal disorder, diabetes, inflammation, bronchitis, thirst, and ulcers [7].

Syzygium genus is also well known for their various clinical scientific reports in medical treatment or prevention, such as antioxidant, antimicrobial (especially against herpes virus), antifungal, antivirus, analgesic, anti-inflammatory, antihypertensive, antihyperglycemic, anticonvulsant, sedative, spasmolytic- cytotoxic activity, and other activities [1,4].

This review systematically described the scientifically proven information of jambu semarang in the topic of phytochemical contents, traditional usage, and pharmacological activities. Hopefully, this article will be useful for future research towards the drug development of $S$. samarangense. 


\section{Materials and Methods}

This review is based on articles collected through literature study from an international scientific journal written in English. Literature findings are conducted with several keywords and inclusion criteria. The keywords are Syzygium samarangense; jambu semarang; phytochemical compounds; traditional uses; pharmacological activities, toxicology. The inclusion criteria include 1) article published from 2010-2020;2) article published from 20182020 with a minimum amount of 20 references; 3) article published in PubMed, Google Scholar, ScienceDirect, Scopus, and CrossRef portal; and 4) article must have DOI (digital object identifier). The selection of articles is conducted with PRISMA (Preferred Reporting Items for Systematic Review and Meta-Analysis) method to ensure that authors have a good quality of the article.

\section{Results and Discussion}

\subsection{Phytochemical compounds of S. samarangense.}

S. samarangense produces both primary metabolites and secondary metabolites. The primary metabolites of the plant consist of nutritional compounds, such as carbohydrates, proteins, lipids, amino acids, nucleic acids, fatty acids, vitamins, and minerals which are distributed in various parts of the plant. Metabolite production of the plant is highly affected by the environmental status, the use of growth regulators, local living pests, and storage methods [18]. The juicy content of the fruits' flesh consists of protein (92.9\%), carbohydrate $(6 \%)$, crude fiber $(0.46 \%)$, and ash minerals $(0.21 \%)$. A water-soluble polysaccharide fraction (WAFP) study isolated from the fruit also consists of rhamnose, arabinose, xylose, mannose, glucose, and galactose molar ratio of $1.88 ; 2.20 ; 6.37 ; 1.48 ; 5.47$; and 2.82 [19]. Nutritional values of the fruit for every $100 \mathrm{~g}$ can be seen in Table 1 [12].

Table 1. Nutritional values of jambu semarang fruit [12].

\begin{tabular}{l|c}
\multicolumn{1}{c|}{ Nutrition } & Amount (for every 100 g fruits) \\
\hline Calorie & $34 \mathrm{Kcal}$ \\
\hline Water & $90.6 \mathrm{~g}$ \\
\hline Crude protein & $0.5 \mathrm{~g}$ \\
\hline Crude fat & $0.2 \mathrm{~g}$ \\
\hline Carbohydrate & $8.6 \mathrm{~g}$ \\
\hline Crude fiber & $0.6 \mathrm{~g}$ \\
\hline Dietary fiber & $1 \mathrm{~g}$ \\
\hline Ash & $0.2 \mathrm{~g}$ \\
\hline Vitamin B1 & $0.02 \mathrm{mg}$ \\
\hline Vitamin B2 & $0.03 \mathrm{mg}$ \\
\hline Vitamin B6 & $0.03 \mathrm{mg}$ \\
\hline Niacin & $0.03 \mathrm{mg}$ \\
\hline Vitamin C & $6 \mathrm{mg}$ \\
\hline Sodium & $25 \mathrm{mg}$ \\
\hline Potassium & $340 \mathrm{mg}$ \\
\hline Calcium & $28 \mathrm{mg}$ \\
\hline Magnesium & $13 \mathrm{mg}$ \\
\hline Phosphorus & $35 \mathrm{mg}$ \\
\hline Iron & $1.5 \mathrm{mg}$ \\
\hline Zinc & $0.2 \mathrm{mg}$
\end{tabular}


Analysis of $S$. samarangense roots dry powder extracted in methanol and ethyl acetate solvents reported that there are several biochemical compounds obtained (w/w), which are amino acids $(4.25 \pm 0.28 \%)$, proteins $(2.69 \pm 0.17 \%)$, soluble sugars $(1.11 \pm 0.09 \%)$, crude fiber $(0.41 \pm 0.12 \%)$, crude fat $(3.36 \pm 0.23 \%)$, crude protein $(5.81 \pm 0.36 \%)$, nitrogen $(2.71 \pm$ $0.14 \%)$, ash $(6.49 \pm 0.26 \%)$, and acid insoluble ash $(0.37 \pm 0.17 \%)$. There are metals and various minerals present in the roots of the plant extracted using acid digestion. Sodium and potassium content had the highest number compared to calcium, magnesium, iron, manganese, zinc, copper, cobalt, cadmium, mercury, and silver, based on atomic absorption spectrophotometry (AAS) and flame-photometer measurement [20].

The leaves of $S$. samarangense contained many compounds, which are flavonoids, phenolic compounds, tannins, terpenoids, and sterols. Other metabolite groups, such as volatile oils, sysamarins A-E [21], sysamarins F-G [22], phloroglucinols [23], essential oils [24], resorcinol derivatives [25], also were examined in the past study.

A study found that the first example of 23 long carbon chain aliphatic ester of ursane and oleanane triterpenoids were isolated from Syzygium genus. Those compounds were four unidentified ursane triterpenoids, sysamarins A-D, along with an undescribed oleanane triterpenoid, sysamarin E, isolated from leaves by ethyl acetate solvent. Elucidation of these structures was conducted by extensive spectroscopy method including High ResolutionElectrospray Ionization-Mass Spectrometry (HR-ESI-MS) spectroscopy[21]. Other oleanane triterpenoids, sysamarins F-G, were isolated from the leaves along with one known analog that have a long aliphatic chain at carbon 23 position. Oleanane triterpenoids could be developed as potential chemotaxonomic markers of Syzygium genus [22].

A systematic investigation utilizing HR-ESI-MS/MS analysis led to acylphloroglucinol, a rare phytochemical group in the higher plant yet common to be found Syzygium genus. The experiment revealed nine acylphloroglucinol derivatives isolated from the leaves of the plant. Four compounds among them were new acylphloroglucinol derivatives, samarones $\mathrm{A}-\mathrm{D}$, which are connected to alkyl side chain at $\mathrm{C}_{17}$ position and comprised a methylated 5,7-dihydroxy-chromone core [23].

Resorcinol derivatives with long aliphatic chain were isolated from jambu semarang leaves. There are nine resorcinol derivatives, with 5-[(8Z,11Z,14Z)-nonadeca-8,11,14-trienyl] resorcinol and 5-[(8Z,11Z,14Z)-heptadeca-8,11,14-trienyl] resorcinol reported as the newly discovered structure. Four of nine isolated resorcinol derivatives, which were 5-[(8Z,11Z,14Z)heptadeca-8,11,14-trienyl] resorcinol, 5-[(9Z,12Z)-heptadeca-9,12-dienyl] resorcinol, 5-[(Z)heptadeca-10-enyl] resorcinol, and 5-[(Z)-pentadecyl-10-enyl] resorcinol, demonstrated a significant inhibitory effect towards $\alpha$-glucosidase. The other resorcinol derivatives were 5[(Z)-nonadecyl-14-enyl] resorcinol, 5-pentadecyl resorcinol, and 5-heptadecane resorcinol [25].

A chalcone, namely aurentiacin, was isolated from jambu semarang leaves [26]. There were also novel proanthocyanins founded in the leaves with double-bond structures, which are samarangenins A and B [8]. Study n-hexane extract of the leaves confirmed the presence of $\alpha-$ carotene, $\beta$-carotene, lupeol, betulin, epibetulinic acid, 2',4'-dihydroxy-6'-methoxy-3'methylchalcone, 2'-hydroxy-4',6'-dimethoxy-3'-methylchalcone, 2'-4'-dihydroxy-6'methoxy-3',5'-dimethylchalcone, 2',4'-dihydroxy-6'-methoxy-3'-methyldihydrochalcone, 7hydroxy-5-methoxy-6,8-dimethylflavanone, 2'-hydroxy-4',6'-dimethoxy-3'- methyl dihydro chalcone, and 2',4'-dihydroxy-6'-methoxy-3',5'-dimethyldihydrochalcone [3]. Sterols were also isolated ( $\beta$-sitosterol and $\beta$-D-sitosteryl glucoside) [8]. 
Essential oils were represented in a study of hydro-distilled leaves of $S$. samarangense cultivated from Egypt's Cairo-Alexandria desert. The essential oil of the leaves mainly composed of mono- and sesquiterpenes. Those terpenes included germacrene D $(21.62 \%)$, cuminyl aldehyde $(10.56 \%), \beta$-caryophyllene $(5.93 \%), \delta$-cadinene $(5.25 \%)$, spathulenol $(4.53 \%)$, anethole (4.25\%), caryophyllene oxide (3.35\%), and 84 other minor components [24]. Another study on the plant cultivated from Mauritius confirmed the presence $\beta$-pinene $(21.3 \%)$, $\alpha$-pinene (8.9\%), $\gamma$-terpinene (7.9\%), limonene (7.7\%), p-cymene (5.9\%), $\beta$-selinene $(3.8 \%)$, selin-11-en-4- $\alpha$-ol (3.6\%), $\beta$-caryophyllene (3.5\%), $\alpha$-selinene $(3.4 \%), \delta$-cadinene $(2.9 \%), 1$ epi-cubenol (2.2\%), terpinolene (2.1\%), and $\alpha$-terpineol (2.1\%) [27].

Not only mono- and sesquiterpenes, other class terpenes, including triterpenoids and steroid groups, are also present in $S$. samarangense. These mainly consist of stearate, lupenyl stearate, sitosteryl stearate, and 24-methylenecycloartanyl stearate which were discovered from air-dried leaves of jambu semarang in dichloromethane extract [28]. A follow-up study carried out in the Philippines found that there were ursolic acid and lupeol in dichloromethane fractions of jambu semarang leaves. Ursolic acid was known for its anti-tumorigenic and chemopreventive activity [29].

Several compounds were repeatedly founded in the various study. A study of $S$. samarangense leaves in methanol extract isolated 14 known compounds, lupeol, demethoxymatteucinol, cryptostrobin, betulinic acid, $\beta$-sitosterol glucoside, $2 \mathrm{R}$-prunasin, myrciaphenone A, 1-feruloyl- $\beta$-D-glucopyranoside, $(3 S, 5 R, 6 R, 7 E, 9 S)$ - 3,5,6,9-tetrahydroxy megastigman-7-ene, guaijaverin, and myricetin 4'-methyl ether 3-O- $\alpha$-L-rhamno-pyranoside. The same study also reported cyanogenic glucoside (taxiphyllin 6'-O-gallate), megastigmane glucoside (actinidioionoside 6'-O-gallate), and sulfated flavonoid rhamnoside (myricetin 2"$O$-sulfate) as newly discovered compounds [30].

Phytochemical compounds investigation of $S$. samarangense bark extract indicated the presence of reducing sugar, tannins, flavonoids, saponins, gum, and alkaloids [7]. The flowers produce tannins [8], while the plant's fruits contain jasmonic acid and salicylic acid. During the post-harvesting process, the content of these components will be significantly reduced due to their roles in pathogenic resistance. The more duration of post-harvest shelf life, the more visible diseases appeared [15]. Two flavonol glycosides (epigallocatechin 3-O-gallate and epicatechin-3-O-gallate) also samarangenins A and B were found in the fruit parts. A study on fruits also traced the existence of anthocyanins cyanidin-3-glucoside, flavonoids, quercetin, quercitrin, myricetin, rutin, and ellagic acid [8].

Based on all the analyses below, there are many phytochemical compounds of jambu semarang summarized in Table 2 .

Table 2. Phytochemical compounds of jambu semarang

\begin{tabular}{|c|c|c|c|}
\hline Plant Parts & Metabolites Groups & Compounds & References \\
\hline Leaves & \multirow[t]{11}{*}{ Flavonoids } & 2',4'-Dihydroxy-6'-methoxy-3'- methyl dihydrochalcone & [3] \\
\hline & & 2'-Hydroxy-4',6'-dimethoxy-3'- methyl dihydrochalcone & [3] \\
\hline & & 2',4'-Dihydroxy-6'- methoxy $3^{\prime}, 5^{\prime}$ - dimethyl dihydrochalcone & [3] \\
\hline & & 2'-Hydroxy-4',6'-dimethoxy-3'- methyl chalcone & [3] \\
\hline & & 2',4'-Dihydroxy-6'-methoxy-3'- methyl chalcone (Stercurensin) & [3] \\
\hline & & 2',4'-Dihydroxy-6'-methoxy- 3',5' dimethyl chalcone & [3] \\
\hline & & Pinocembrin & [3] \\
\hline & & (一)-Strobopinin & [3] \\
\hline & & 8-Methylpinocembrin & [3] \\
\hline & & Demethoxymatteutcinol & [3] \\
\hline & & 7-Hydroxy-5-methoxy-6,8- dimethyl-flavanone & [3] \\
\hline \multicolumn{2}{|c|}{ https://biointerfaceresearch.com/ } & & 2088 \\
\hline
\end{tabular}




\begin{tabular}{|c|c|c|c|}
\hline Plant Parts & Metabolites Groups & Compounds & References \\
\hline & & $\begin{array}{l}\text { 7,8,3',4'-tetrahydroxy-3,5- dimethoxyflavone (3,5-di- } O \text {-Methyl } \\
\text { Gossypetin) }\end{array}$ & [31] \\
\hline & & 5.7-Dihydroxy-6,8- dimethyl flavanone & [32] \\
\hline & & (一)-Epigallocatechin & {$[3]$} \\
\hline & & (-)-Epigallocatechin 3-O-gallate & [3] \\
\hline & & Myricetin 4'-methyl ether 3-O- $\alpha$-L-rhamno-pyranoside & [30] \\
\hline & & Myricetin 2'-O-sulfate & [30] \\
\hline & & Myricetin-3-O-rhamnoside & [31] \\
\hline & & Mearnsitrin & {$[3]$} \\
\hline & & Samarangenins A & [3] \\
\hline & & Samarangenins B & [3] \\
\hline & & Prodelphinidin B-2 3"-O- gallate & [3] \\
\hline & & Prodelphinidin B-2 3,3"-O-gallate & [3] \\
\hline & & Aurentiacin & [26] \\
\hline & & Cryptostrobin & [30] \\
\hline & & Guaijaverin & [30] \\
\hline & \multirow[t]{9}{*}{ Resorcinol } & 5-[(8Z,11Z,14Z)-nonadeca-8,11,14-trienyl] resorcinol & [25] \\
\hline & & 5-[(8Z,11Z,14E)- heptadeca-8,11,14-trienyl] resorcinol & [25] \\
\hline & & 5-[(8Z,11Z,14Z)-heptadeca-8,11,14-trienyl] resorcinol & [25] \\
\hline & & 5-[(9Z,12Z)-heptadeca-9,12-dienyl] resorcinol & [25] \\
\hline & & 5-[(Z)-nonadecyl-14-enyl] resorcinol & [25] \\
\hline & & 5-[(Z)-heptadeca-10-enyl] resorcinol & [25] \\
\hline & & 5-[(Z)-pentadecyl-10-enyl] resorcinol & [25] \\
\hline & & 5-pentadecyl resorcinol & [25] \\
\hline & & 5-heptadecane resorcinol & [25] \\
\hline & \multirow[t]{9}{*}{ Acylphloroglucinols } & Samarone A & [23] \\
\hline & & Samarone B & [23] \\
\hline & & Samarone $\mathrm{C}$ & [23] \\
\hline & & Samarone D & [23] \\
\hline & & 2-Pentadecyl-5,7- didydroxychromone & [23] \\
\hline & & Jamunone B & [23] \\
\hline & & Jambone E & [23] \\
\hline & & Jambone $\mathrm{F}$ & [23] \\
\hline & & Jambone G & [23] \\
\hline & Alkaloids & 2R-prunasin & [30] \\
\hline & \multirow[t]{3}{*}{ Glucose } & $(3 S, 5 R, 6 R, 7 E, 9 S)-3,5,6,9$-tetrahydroxymegastigman-7-ene & [30] \\
\hline & & Taxiphyllin 6'-O-gallate & [30] \\
\hline & & Actinidioionoside 6'-O-gallate & [30] \\
\hline & \multirow[t]{2}{*}{ Phenolic compounds } & Myrciaphenone A & [30] \\
\hline & & 1-feruloyl- $\beta$-D-glucopyranoside & [30] \\
\hline & \multirow[t]{18}{*}{ Terpenoids } & Sysamarin A & [21] \\
\hline & & Sysamarin B & [21] \\
\hline & & Sysamarin $\mathrm{C}$ & [21] \\
\hline & & Sysamarin D & [21] \\
\hline & & Sysamarin E & [21] \\
\hline & & Sysamarin F & [22] \\
\hline & & Sysamarin G & [22] \\
\hline & & Methyl $2 \alpha, 3 \beta, 23$-trihydroxyolean-12-en-28-formate & [22] \\
\hline & & Ursolic acid & [29] \\
\hline & & Ursane & [21] \\
\hline & & Oleanane & [21] \\
\hline & & Cycloartenyl stearate & [28] \\
\hline & & Lupenyl stearate & [28] \\
\hline & & 24-methylenecycloartenyl stearate & [28] \\
\hline & & Lupeol & [29] \\
\hline & & Betulin & {$[3]$} \\
\hline & & Betulinic acid & [3] \\
\hline & & $\beta$-carotene & [8] \\
\hline \multicolumn{2}{|c|}{ https://biointerfaceresearch.com/ } & & 2089 \\
\hline
\end{tabular}




\begin{tabular}{|c|c|c|c|}
\hline \multirow[t]{2}{*}{ Plant Parts } & Metabolites Groups & Compounds & \multirow{2}{*}{$\begin{array}{c}\text { References } \\
{[8]}\end{array}$} \\
\hline & & Epibetulinic acid & \\
\hline & \multirow[t]{3}{*}{ Sterols } & $\beta$ - Sitosteryl stearate & {$[28]$} \\
\hline & & $\beta$-D- Sitosterol glucoside (Daucosterol) & {$[30]$} \\
\hline & & $\beta$-Sitosterol & [29] \\
\hline & \multirow[t]{19}{*}{ Volatile oils } & Germacrene D & {$[24]$} \\
\hline & & Cuminyl aldehyde & {$[24]$} \\
\hline & & $\beta$-Carryophyllene & {$[24]$} \\
\hline & & $\delta$-Cadinene & {$[24]$} \\
\hline & & Spathulenol & {$[24]$} \\
\hline & & Anethole & {$[24]$} \\
\hline & & Caryophyllene oxide & {$[24]$} \\
\hline & & $\beta$-Pinene & {$[27]$} \\
\hline & & $\alpha$-Pinene & {$[27]$} \\
\hline & & $\gamma$-Terpinene & {$[27]$} \\
\hline & & Limonene & {$[27]$} \\
\hline & & p-Cymene & {$[27]$} \\
\hline & & $\beta$-Selinene & {$[27]$} \\
\hline & & Selin-11-en-4- $\alpha$-ol & [27] \\
\hline & & $\alpha$-Selinene & {$[27]$} \\
\hline & & $\delta$-Cadinene & [27] \\
\hline & & epi-ubenol & {$[27]$} \\
\hline & & Terpinolene & {$[27]$} \\
\hline & & $\alpha$-Terpineol & {$[27]$} \\
\hline \multirow[t]{20}{*}{ Fruits } & \multirow[t]{15}{*}{ Flavonoids } & 2',4'-Dihydroxy-3',5'-dimethyl- 6'-methoxychalcone & {$[3]$} \\
\hline & & 2',4'-Dihydroxy-6'- methoxchalcone (Cardamonin) & [3] \\
\hline & & Pinocembrin & [3] \\
\hline & & Quercetin & [3] \\
\hline & & Reynoutrin & [3] \\
\hline & & Hyperin & [3] \\
\hline & & Quercitrin & [3] \\
\hline & & Quercetin & {$[8]$} \\
\hline & & Myricetin & {$[8]$} \\
\hline & & Rutin & {$[8]$} \\
\hline & & Guaijaverin & {$[3]$} \\
\hline & & Epigallocatechin 3-O-gallate & {$[8]$} \\
\hline & & Epicatechin-3-O-gallate & {$[8]$} \\
\hline & & Samarangensis A & {$[8]$} \\
\hline & & Samarangensis B & [8] \\
\hline & Anthocyanins & Cyanidin-3-glucoside & [8] \\
\hline & \multirow[t]{4}{*}{ Acids } & Ellagic acid & [3] \\
\hline & & Gallic acid & [3] \\
\hline & & Jasmonic acid & [15] \\
\hline & & Salicylic acid & {$[15]$} \\
\hline
\end{tabular}

Several S. samarangense metabolites structures are available in Figures 1-3.

\subsection{Traditional uses of S. samarangense.}

S. samarangense has been a part of traditional medicine in several countries in Asia. Bangladeshi used the leaves of $S$. samarangense for cold, itches, and waist pain treatment [33]. Malayan also used the roots preparations for itches to alleviate edema and as a diuretic. The leaves are used for fresh or dry as astringent, treating fever, and halt diarrhea [21]. The barks were prepared by the Indian tribe as an astringent for mouthwash [7]. The decoction of roots and barks was commonly used in dysentery, amenorrhea, menstrual flow stimulator, and abortifacient [3]. 
<smiles>COc1cc(O)c(C)c(O)c1C(=O)CCc1ccccc1</smiles>

2',4'-Dihydroxy-6'-methoxy-3'methyldihydrochalcone<smiles>COc1cc(OC)c(C(=O)CCc2ccccc2)c(O)c1C</smiles>

2'-Hydroxy-4',6'-dimethoxy-3'methyldihydrochalcone<smiles>COc1c(C)c(O)c(C)c(O)c1C(=O)CCc1ccccc1</smiles><smiles>O=C1CC(c2ccccc2)Oc2cc(O)cc(O)c21</smiles><smiles>Cc1c(O)c(C)c2c(c1O)C(=O)CC(c1ccccc1)O2</smiles>

Pinocembrin<smiles>C=C(/C=C\C)C1CC(=O)c2c(cc(O)c(C)c2O)O1</smiles>

(-) Strobopinin<smiles>Cc1c(O)cc(O)c2c1OC(c1ccccc1)CC2=O</smiles>

8-Methylpinocembrin<smiles>Cc1c(O)c(C)c2c(c1O)C(=O)CC(c1ccccc1)O2</smiles>

Demethoxymattheutcinol<smiles>COc1c(C)c(O)c(C)c2c1C(=O)CC(c1ccccc1)O2</smiles>

5.7-Dihydroxy-6,8dimethylflavanone<smiles>Oc1cc(O)c2c(c1)O[C@H](c1cc(O)c(O)c(O)c1)[C@H](O)C2</smiles>

(-) Epigallocatechin<smiles>O=C(O[C@H]1Cc2c(O)cc(O)cc2O[C@@H]1c1cc(O)c(O)c(O)c1)c1cc(O)c(O)c(O)c1</smiles>

2'-Hydroxy-4',6'-dimethoxy-3'methylchalcone<smiles>COc1cc(O)c(C)c(O)c1C(=O)/C=C/c1ccccc1</smiles>

7-Hydroxy-5-methoxy-6,8- dimethyl-flavanone<smiles>COc1c(C)c(O)c(C)c(O)c1C(=O)/C=C/c1ccccc1</smiles>

HO<smiles>[2H]c1cc(OC)c2c(=O)c(OC)c(-c3ccc(O)c(O)c3)oc2c1O</smiles><smiles>CC1OC(Oc2c(-c3cc(O)c(O)c(O)c3)oc3cc(O)cc(O)c3c2=O)C(O)C(O)[C@@H]1O</smiles>

(-) Epigallocatechin-3-O-Gallate

Myricetin-3-O-rhamnoside

2',4'-Dihydroxy-6'-methoxy- 3',5' dimethylchalcone
7,8,3', $4^{\prime}$-Tetrahydroxy-3,5- dimethoxyflavone (3,5-di-O-Methyl Gossypetin)

Taiwanese study reported that the leaves extract has a significant lure effect towards Aedes albopictus mosquito ovitraps. It was an ideal low-to-no-cost bait and simple vector management [34]. In South Asia, the fruit was served both as a hot dish and a cold dish. The hot dish was served as a soup added with crystal sugar to treat non-phlegmy cough. The fruit also was served cold dishes on banquets as an antidote to the alcoholic effect. Tannins, desmethoxymatteucinol, 5-O-methyl-40-desmethoxymatteucinol, oleanic acid, and $\beta$ sitosterol compounds of jambu semarang flower were used to reduce fever and also halt diarrhea [9]. 


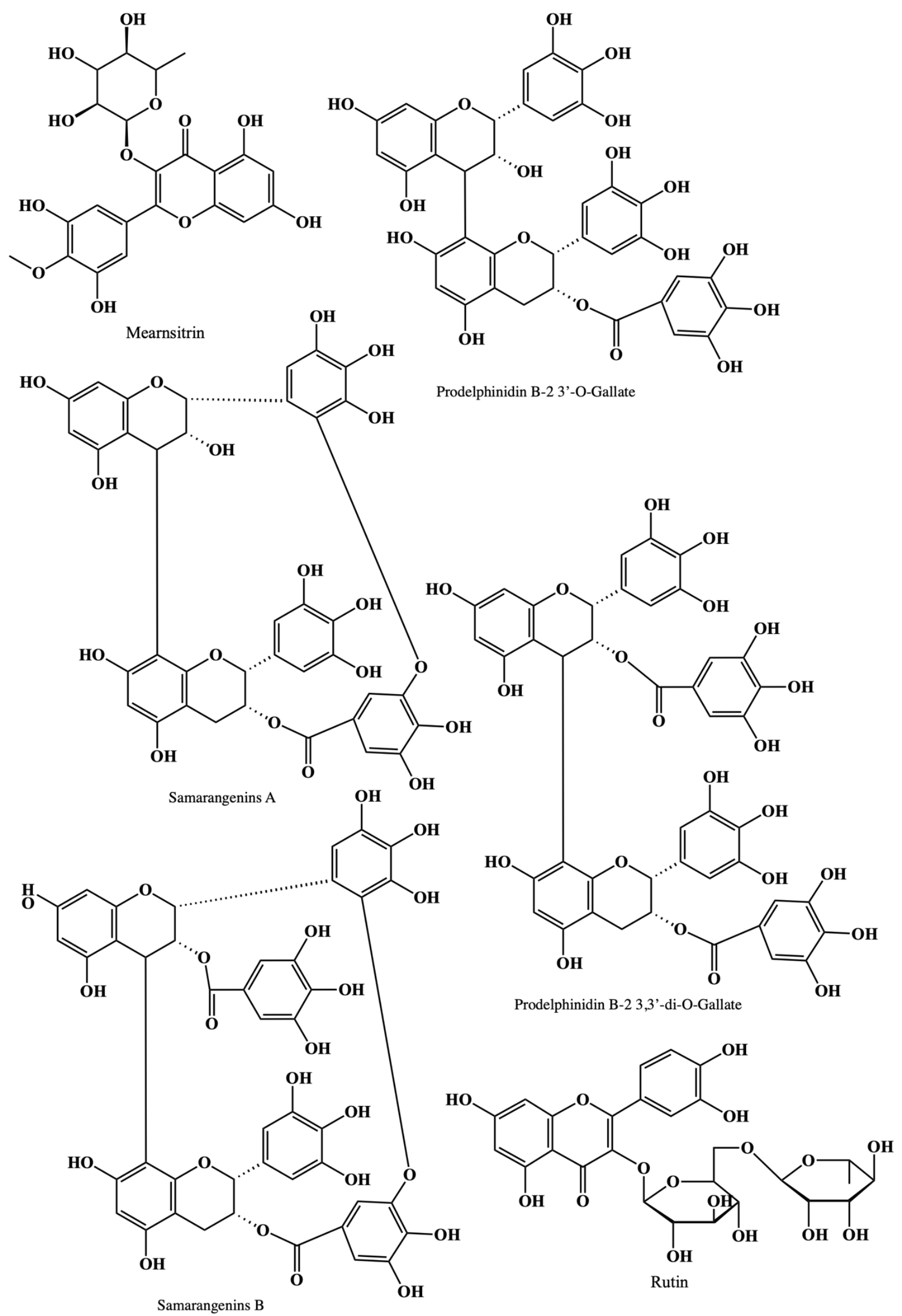


<smiles>COc1c(O)cc(-c2oc3cc(O)cc(O)c3c(=O)c2OC2O[C@H](C)C(O)[C@H](O)[C@H]2O)cc1O</smiles>

Myricetin 4'-methyl ether 3-O- $\alpha$-L-rhamnopyranoside<smiles>[Y20][X]S(=O)(=O)Oc1c(-c2oc3cc(O)cc(O)c3c(=O)c2O)cc(O)c(O)c1O</smiles>

Cryptostrobin<smiles>O=c1c(O)c(-c2ccc(O)c(O)c2)oc2cc(O)cc(O)c12</smiles><smiles>C=CC(=C)c1oc2cc(O)cc(O)c2c(=O)c1OC1OCC(O)C(O)[C@H]1O</smiles><smiles>O=c1c(O)c(-c2ccc(O)c(O)c2)oc2cc(O)cc(O)c12</smiles><smiles>COc1c(C)c(O)c(C)c(O)c1C(=O)/C=C/c1ccccc1</smiles><smiles>C/C=C\CC</smiles>

',4'-Dihydroxy-3',5'-dimethyl- 6'-methoxychalcone

Myricetin-2'-O-sulfate<smiles>COc1cc(OC)c(/C=C/C(=O)c2ccccc2)c(O)c1C</smiles><smiles>COc1cc(OC)c(/C=C/C(=O)c2ccccc2)c(O)c1C</smiles><smiles>C/C=C/C(=O)c1c(O)cc(O)cc1OC</smiles><smiles>OCc1ccccc1</smiles><smiles>OCO</smiles><smiles>C=C(C=CC)c1oc2cc(C)cc(O)c2c(=O)c1O</smiles><smiles>O=C1CC(c2ccccc2)Oc2cc(O)cc(O)c21</smiles><smiles>O=C1CCCCC1</smiles><smiles>[Mg][Mg]</smiles><smiles>CC(O)CO</smiles>
Myricetin<smiles>O=c1c(OC2OC[C]3CCCCC32)c(-c2ccc(O)c(O)c2)oc2cc(O)cc(O)c12</smiles>

Reynoutrin

Figure 1. Representative chemical structures of flavonoids isolated from jambu semarang.

\subsection{Pharmacological activities of S. samarangense.}

Alongside the traditional uses, phytochemicals of jambu semarang are reported to have several pharmacological actions with prospective medical benefits such as antioxidant, antimicrobial (especially against herpes virus), analgesic, anti-inflammatory, antihypertensive, antihyperglycemic, anticonvulsant, sedative, astringent, spasmolytic, inhibitor of histamine release, potential inhibitor on peripheral blood mononuclear cells, cytotoxic activity, 
immunomodulator, diabetes or glucose tolerance impairment, skin diseases, tuberculosis, diarrhea, stomach, and respiratory complaints management [12].

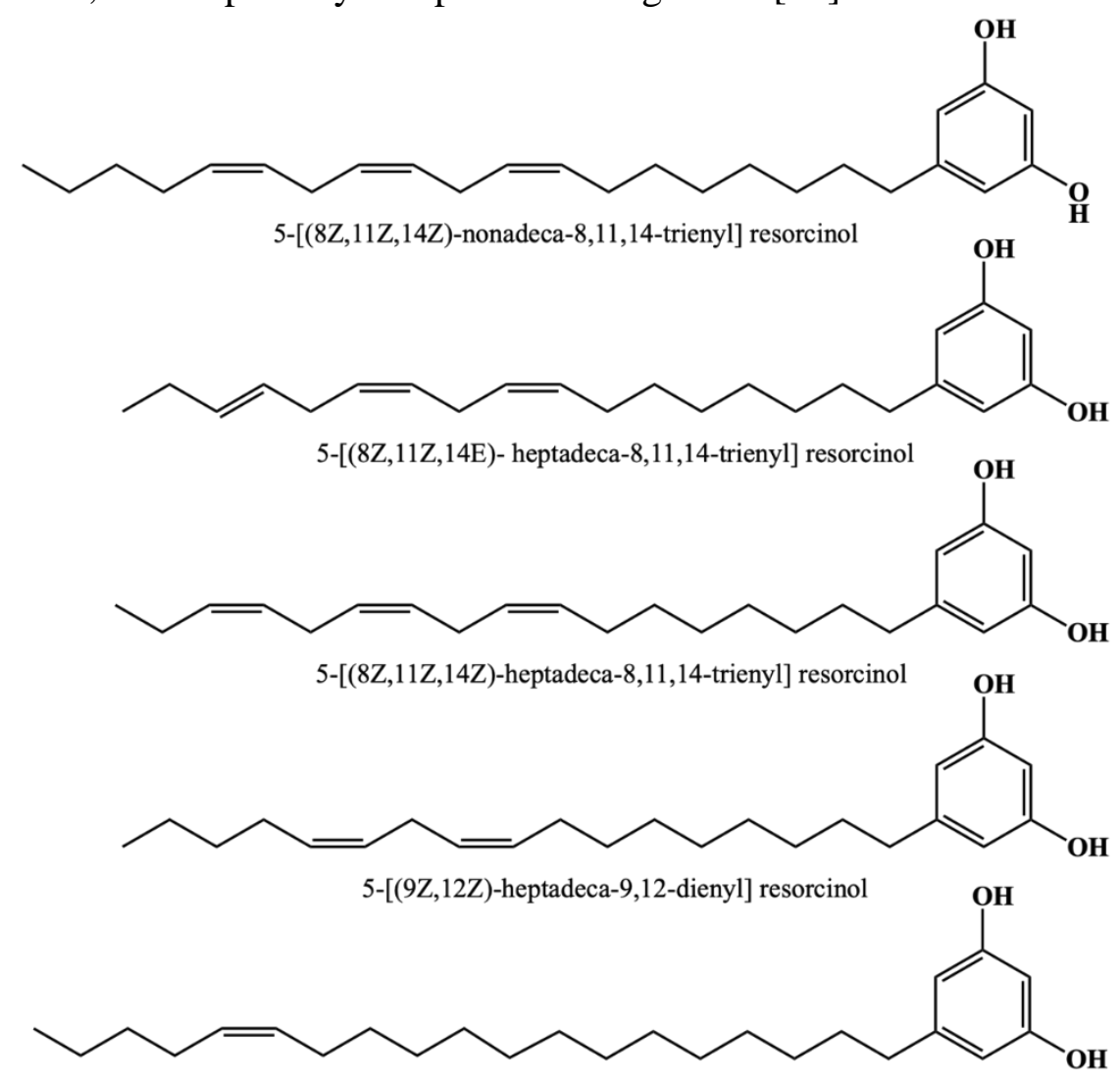

5-[(Z)-nonadecyl-14-enyl] resorcinol

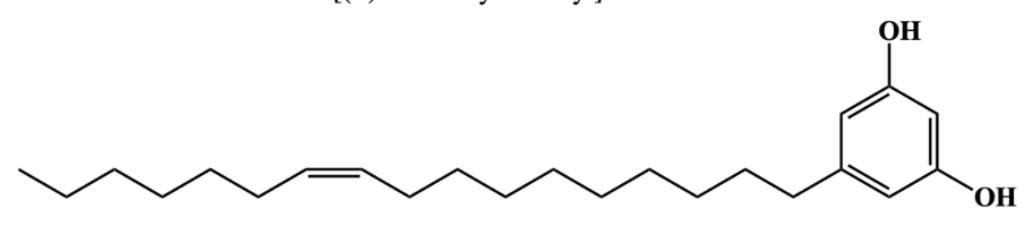

5-[(Z)-heptadeca-10-enyl] resorcinol

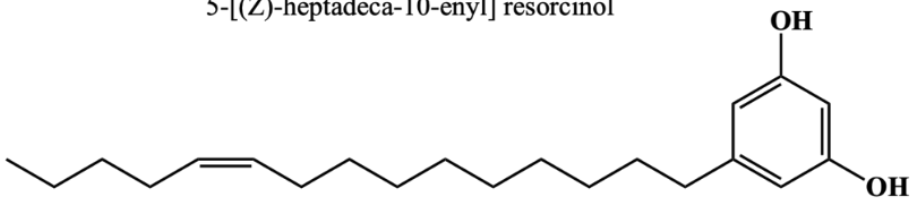

5-[(Z)-pentadecyl-10-enyl] resorcinol

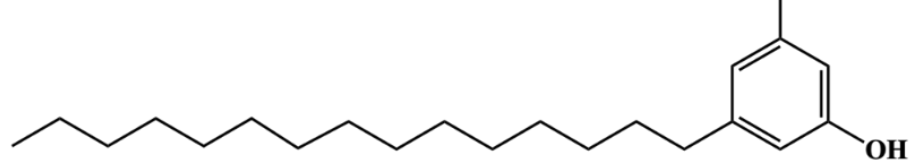

5-pentadecyl resorcinol

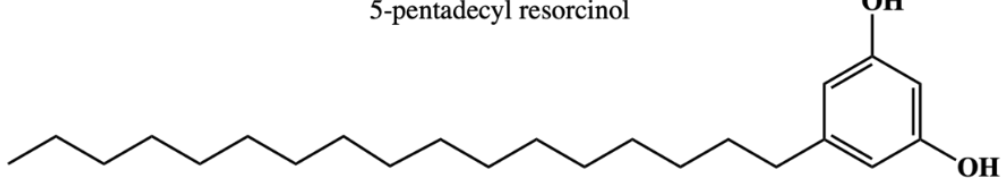

5-heptadecane resorcinol

Figure 2. Representative chemical structures of resorcinol derivatives isolated from jambu semarang.

\subsubsection{Antioxidant activity.}

The antioxidant activity is commonly linked to the presence of phenolic compounds with numerous hydroxyl moieties such as flavonoids and coumarins [32]. Being rich in flavonoids, jambu semarang provides an effective antioxidant measure [31]. 
A study with ethyl acetate extract of $S$. samarangense reported the presence of antioxidant activity using the DPPH method with $\mathrm{IC}_{50}$ estimated $74.37 \mu \mathrm{g} / \mathrm{ml}$. Myricitrin (myricetin-3-O$\alpha$-rhamnoside) compound of leaves crude extract was reported to modulate the mitogenactivated protein kinase (MAPK) signaling pathway to counter the activation of oxidative stress.

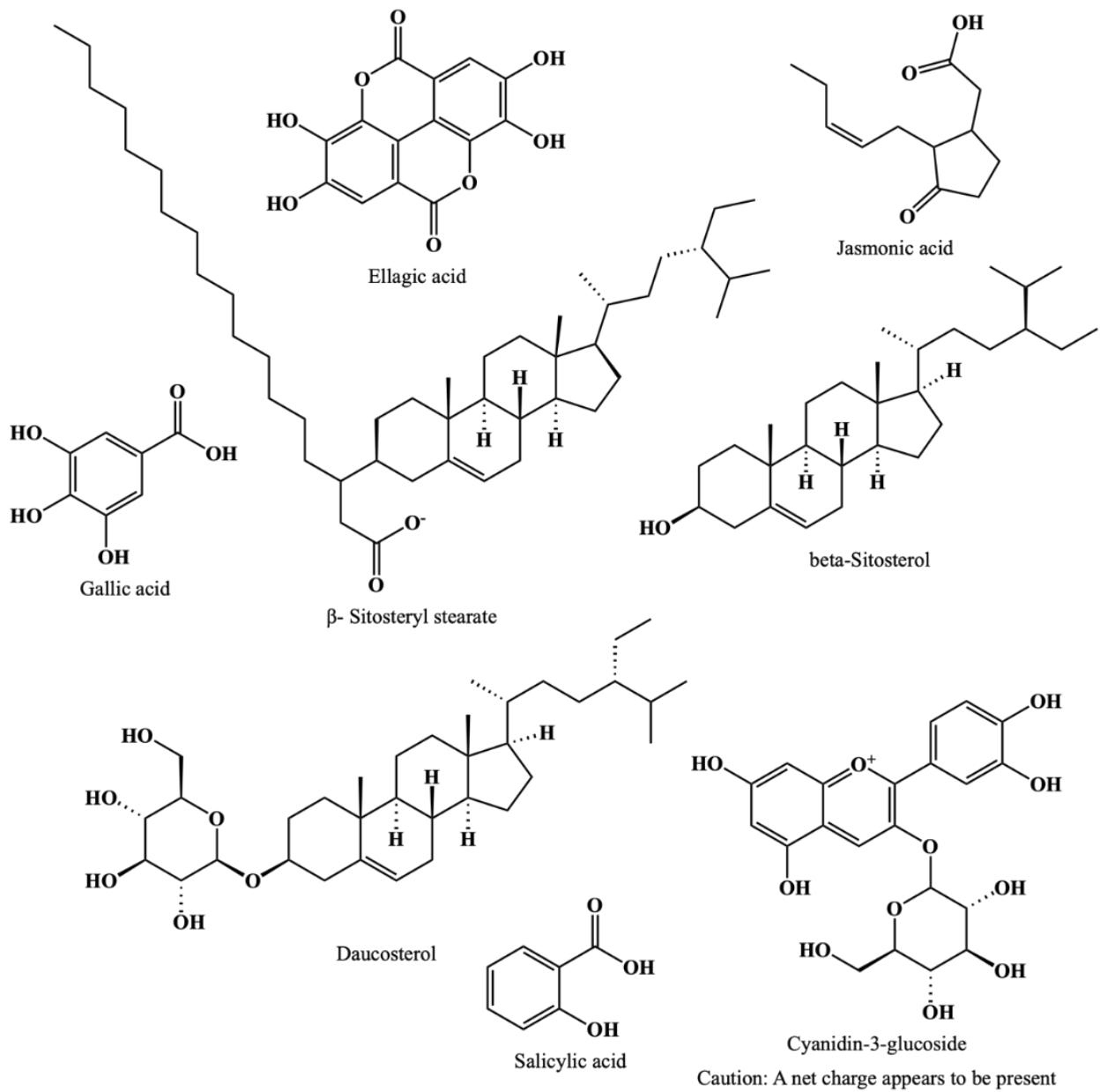

Figure 3. Representative chemical structures of sterols, anthocyanins, and acids isolated from jambu semarang.

The same research also found where 3,5-di-O-methyl gossypetin (7,8,3 ,4 tetrahydroxy-3,5-dimethoxyflavone) reported the same mechanism by modulating the nuclear transcription factor-2 (Nrf-2) signaling pathway and stimulate the phase II detoxifying enzymes expression, such as HO-1 enzyme and Mn-SOD-3 enzyme. Both metabolites showed an in vitro antioxidant activity by lowering the negative effects of oxidative stress in HaCaT cells. Glutathione level was observed from a constant amount of reactive oxygen species (ROS) [31].

The methanolic extract of $S$. samarangense roots showed a moderate antioxidant activity using DPPH and FRAP assays with gallic acid as the biomarkers [3]. The roots of the plant extracted continuously in three different solvents (ethyl acetate, methanol, and water) by the Soxhlet apparatus method, reported an antioxidant activity that was evaluated by DPPH (2,2-diphenyl-1-picrylhydrazyl) radical scavenging compared with ascorbic acid. Methanolic extracts with the highest scavenging percentage contained flavonoids at $33.687 \mu \mathrm{g} / \mathrm{g}$ extract [3].

There are three variants of $S$. samarangense based on their fruit color (red, pink, and green). Antioxidant activity measurement using the DPPH method with ascorbic acid as the standard showed that the extract of the red fruit variants had the highest antioxidant activity, 
followed by the pink and green variants, respectively [9]. Further studies need to be conducted to analyze the correlation between fruit pigmentation and antioxidant activity.

Antioxidant effect was also found in eight phytochemicals that were identified from the fruits. Those compounds are six quercetin glycosides (reynoutrin, hyperin, myricitrin, quercitrin, quercetin, and guaijaverin), (S)-pinocembrin, and phenolic acid (gallic acid and ellagic acid) [3]. Another study also showed that fruit ethanolic extract expressed moderate antioxidant activity with $\mathrm{IC}_{50}$ of $77.51 \mathrm{mg} / \mathrm{ml}$, TAC (total anthocyanins content) of $0.07 \mathrm{mg}$ $\mathrm{C} 3 \mathrm{G} / \mathrm{g}$ dry weight, and TPC (total phenolic content) of $18.04 \mathrm{mg}$ GAE (gallic acid equivalent)/g dry weight. The same report with DPPH assay exhibit an IC50 of $200 \mathrm{mg} / \mathrm{ml}$ [8].

Antioxidant activity of jambu semarang twigs and leaves extract was examined with DPPH, ABTS (2,2-azino-bis (3-ethyl-benzthiazoline-6-sulfonic acid)), DMPD (dimethyl-4phenylenediamine), nitrite radical scavenging, and ferrous-ion chelating activity. This study also measured the activity by several assays, including cupric reducing antioxidant capacity, reducing power, ferric reducing antioxidant power, total phenol content, and total flavonoid content. The results dominantly showed that the twigs extract had a stronger antioxidant activity than the leaves due to its higher total phenol and flavonoid contents [36].

\subsubsection{Antimicrobial activity.}

Antimicrobial activities are generally correlated with several phenolics killing the bacteria or suppress virulence factors. The phenolic compound will decrease the amount of important substrate for microbial growth, enzyme inhibition, and chelate complex formation by modifying cytoplasmic membrane permeability [37]. Antimicrobial activity claims can be made by in vitro assay. A molecule is considered antibacterial activity whenever the minimum inhibitory concentrations (MIC) fall below $1000 \mu \mathrm{g} / \mathrm{mL}[3]$.

Volatile oils of $S$. samarangense leaves extract showed antimicrobial activity towards a wide range of enteric and nosocomial pathogenic bacteria that cause diarrhea, such as Escherichia coli, Klebsiella oxytoca, Klebsiella pneumoniae, Proteus vulgaris, Pseudomonas aeruginosa, Salmonella enteritidis, Salmonella paratyphi, Salmonella typhimurium, Shigella dysenteriae and Shigella sonnei [1]. Antibacterial activity of S. semarangense volatile oil was assessed by microdilution method and reported that it was most active toward $S$. typhimurium with $\mathrm{IC}_{50}$ of $0.17 \pm 0.005 \% \mathrm{v} / \mathrm{v}$ [38]. Recent evaluation towards antimicrobial effect in volatile oil of jambu semarang leaves showed the inhibition on E. coli 25922 growth with $\mathrm{IC}_{50}$ of $0.42 \%$ (v/v) [39].

Another study on volatile oil of $S$. samarangese showed the higher activity of the oil against Gram-positive, where Bacillus spizizenii was the most susceptible one, compared to Gram-negative bacteria. The oil composed of terpenes including $\beta$-pinene (21.3\%), $\alpha$-pinene (8.9\%), $\gamma$-terpinene (7.9\%), limonene (7.7\%), p-cymene (5.9\%), $\beta$-selinene $(3.8 \%)$, selin-11en-4 $\alpha$-ol (3.6\%), $\beta$-caryophyllene (3.5\%), $\alpha$-selinene (3.4\%), $\delta$-cadinene (2.9\%), 1-epicubenol (2.2\%), terpinolene (2.1\%), and $\alpha$-terpineol (2.1\%) [27]. The antibiotic potentiating effect of this extract showed a synergic antibacterial efficacy by reducing concentration due to its combination with antibiotic in a 1:1 ratio. Ciprofloxacin, chloramphenicol, and streptomycin were used in this experiment. These findings were valuable for further studies to tackle antimicrobial resistance after safety was established [27]. Further pharmacological investigations will be necessary to validate its medical applications. 
A previous antibacterial study found that the ethanolic extract of jambu semarang leaves consisted of flavonoids, tannins, alkaloids, and terpenoids. This study was conducted using the microdilution method to obtain minimum inhibitory concentration (MIC). The sample of this study were E. coli, Bacillus cereus, Enterobacter aerogenes, and Salmonella enterica. It was shown that there was an effective antibacterial activity against B. cereus and S. enterica compared to chloramphenicol as a biomarker, where both the MIC value obtained were $78 \mu \mathrm{g} / \mathrm{ml}[39]$.

Desmethoxymatteucinol, 5-O-methyl-4'-desmethoxymatteucinol, oleanic acid, and $\beta$ sitosterol of the flower demonstrated a weak antibiotic action against $\mathrm{S}$. aureus, Mycobacterium smegmatis, and Candida albicans [8]. Further study needs to be conducted to find the specific phytochemical compound with antibacterial activity.

\subsubsection{Antiviral (anti-HIV) activity.}

Oleanic acid was well known as an effective anti-HIV compound. These compounds are also present in the leaves of $S$. samarangense. In vivo study was conducted by cultures of human peripheral mononuclear cells (PBMC) and monocyte (macrophage) showed that oleanic acid inhibited replication event of human immunodeficiency virus-1 (HIV-1) in the cellular systems [8]. Further study needs to be conducted with an animal model in vitro assay.

\subsubsection{Analgesic activity.}

Cycloartenyl stearate, lupenyl stearate, sitosteryl stearate, and 24methylenecycloartanyl stearate were discovered from air-dried leaves of jambu semarang in dichloromethane extract. These components demonstrated a potent analgesic activity respectively at $6.25 \mathrm{mg} / \mathrm{kg}$ body weight [28].

Analgesic activity of ethanolic extract of jambu semarang bark was measured using acetic acid-induced writhing and formalin test. The results at the dose $100 \mathrm{mg} / \mathrm{kg}$ and 200 $\mathrm{mg} / \mathrm{kg}$ significantly showed that the extract reduced the writhing and the licking repetition number induced by acetic acid and formalin, respectively, in a dose-dependent manner. A preclinical experiment of ethanolic extract of the barks at the dose of $100 \mathrm{mg} / \mathrm{kg}$ and $200 \mathrm{mg} / \mathrm{kg}$ body weight on swiss-albino mice showed a significant depressant activity manifesting in the reduction of locomotor, exploratory in the open field, and hole cross test activity [40].

Stercuresin (2', 4'-dihydroxy-6'-methoxy-3'methylchalcone), an isolated compound of S. semarangense leaves, has anti-inflammatory activity by in vivo assay with a mouse model. Expression of lipopolysaccharide-induced iNOS (inducible nitric oxide synthase) and cyclooxigenase-2 (COX-2) of isolated mouse peritoneal macrophages were reduced during pretreatment. Thereby, it inhibited nitric oxide (NO) and prostaglandin $\mathrm{E}(2)$ production. Stercuresin downregulated NF-кB dependent pro-inflammatory mediators and cytokines pathways through the attenuated complex formation of TAK-1 and TAB1 (activator subunit of TAK1) [8].

\subsubsection{Anti-inflammatory activity.}

The same study was discovered cycloartenyl stearate, lupenyl stearate, sitosteryl stearate, and 24-methylenecycloartanyl stearate from air-dried leaves of jambu semarang in dichloromethane extract revealed a potent anti-inflammatory activity respectively at 12.15 $\mathrm{mg} / \mathrm{kg}$ body weight [28]. In vitro experiment reported that oleanic acid and ursolic acid 
effectively protect the liver from chemical-induced injury, anti-inflammatory, and antihyperlipidemic. Oleanic acid and ursolic acid were qualified to be non-toxic compounds and had been used in cosmetic and health products [8].

The previous research also found that myricetin-3-O- $\alpha$-rhamnoside and 3,5-di-Omethyl gossypetin (7,8,3,4 -tetrahydroxy-3,5-dimethoxyflavone) expressed an in vitro antiinflammatory activity by strongly reduced intracellular reactive oxygen species (ROS) accumulation, carbonyl content and protected the glutathione (GSH) levels in human keratinocyte cells (HaCaT) after exposure to the sodium arsenite $\left(\mathrm{NaAsO}_{2}\right)$ as a toxic agent. Therefore, both compounds contributed to lower the adverse effects from oxidative stress in $\mathrm{HaCaT}$, inhibit I- $\mathrm{kB}-\alpha$ degradation, and protecting cells from UVA-induced inflammation [31].

Aurentiacin, a chalcone isolated from jambu semarang leaves, was reported to have an anti-inflammatory effect. In vivo study showed this activity towards lipopolysaccharide (LPS)stimulated mouse macrophages by inhibiting the production of LPS-induced nitric oxide in RAW264.7 cell parallel with suppressing the expression of inducible nitric oxide synthase (iNOS). Electrophoretic mobility shift and reporter gene assay at the molecular level reported that there was a reduction of pro-inflammatory cytokines (tumor necrosis factor- $\alpha$ and interleukin-6). Aurentiacin alleviated DNA binding, transcriptional activities of NF- $\mathbf{k B}$, also attenuated phosphorylation and acetylation of 065 and MAPKs. In vitro study with animal model injected by intraperitoneal also showed a decrease in the number of pro-inflammatory cytokine release. Ex vivo experiment also reported a decent decrease of iNOS protein level related to the inhibition of NF- $\mathrm{\kappa B}$ activation [26].

Evaluation of ethyl acetate, methanol, and water root extract showed the antiinflammatory effect following albumin denaturation assay. Methanolic extract showed the highest activity, followed by water and ethyl acetate extract, respectively [3]. Ethanolic extract of barks also gave a potential anti-inflammatory in mice. Carrageenan induced hind paw edema model was used in this study, and the inhibition appeared after $4 \mathrm{~h}$ at the dose $100 \mathrm{mg} / \mathrm{kg}$ and $200 \mathrm{mg} / \mathrm{kg}$ in a dose-dependent manner [40]

\subsubsection{Antidiabetic activity.}

Flavonoids isolated S. samarangense was reported to have antihyperglycemic activity on alloxan-induced diabetic mice [3]. Further study finds that vescalagin is responsible in ameliorating hyperglycemia and hypertriglyceridemia effect on high-fructose diet-induced diabetic rats [41].

Flavonoids isolated from leaves significantly affected lowering the blood glucose level (BGLs) in glucose-hyperglycemic mice. The extract was administrated $15 \mathrm{~min}$ after a glucose load. Those flavonoids were 2',4'-dihidroxy-3',5'-dimethyl-6'-methoxychalcone and its isomeric flavanones (5-O-methyl-4'-desmethoxhymatteucinol and 2',4'-dihidroxy-6'methoxy-3'-methylchalcone) [8].

In carbohydrates metabolism, the aqueous fruit extract of jambu semarang had the potential to mitigate the hyperglycemia of diabetes mellitus (DM) type 2 by increasing the glycogen storage, glycolysis and gluconeogenesis activity, expression of glycogen synthase (GS), hexokinase (HXK), glucose-6-phosphate dehydrogenase (G6PD), phosphofructokinase (PFK), and aldolase. The study was conducted using FL83B mouse hepatocytes that treated with TNF- $\alpha$ to induce insulin resistance and evaluated by examining the uptake of 2-[N-(7- 
nitrobenz-2-oxa-1, 3-diazol-4-yl)amino]-2-deoxyglucose (2 NBDG), a fluorescent D-glucose derivative, and analyzed with Western blot assay [42].

An ellagitannin called vescalagin decreased the expression of pro-inflammatory factors that may cause the excessive metabolism of insulin secretion in $\beta$-cells of rats - this metabolism in human-caused the excessive formation of methylglyoxal (MG), a derivate of pyruvic acid. Further studies of vescalagin on MG metabolism signaling pathway need to be done[43].

A study on the diabetic rat model showed that oral administration of vescalagin alleviated hyperglycemic shown by reducing the glucose level following oral glucose tolerance test. It also reduced cardiovascular risk index, advanced glycation end products (AGEs), and tumor necrosis factor- $\alpha$ contents. Antiglycation was facilitated by increasing D-lactate that retard AGE formation and decreasing cytokine release to prevent $\beta$-cell damage of $\mathrm{MG}$ induced carbohydrate metabolic disorder in rats. This study has proven that vescalagin has a preventive effect on MG-induced inflammation and carbohydrate metabolic disorder in rats [43].

Another vescalagin study showed an ameliorative effect on hepatic insulin resistance cascades and abnormal carbohydrates in the high-fructose diet (HFD)-induced hyperglycemic Wistar rats. The hypoglycemic activity of the compound was confirmed in oral glucose tolerance test and homeostasis model assessment of insulin resistance index. Abnormal carbohydrate metabolism was improved by modulating hepatic gluconeogenesis, glycolysis, and glycogenesis [44].

Methanolic leaves extract was evaluated to have an antihyperglycemic potential carried oral glucose tolerance test in glucose-loaded mice. Methanol extract administered at different doses an hour after glucose administration and BGLs are measured with the glucose oxidase method. The results stated that there was a $59.3 \%$ reduction in serum glucose level. Meanwhile, glibenclamide, as a controlled drug, only reduced 57.3\% [33].

$S$. samarangense extract could reduce insulin resistance by inhibiting inflammatory pathways, insulin signaling activation, glucose uptake improvement in insulin-resistance mouse hepatocytes $[3,42,45]$.

Fruit of jambu semarang had a big role in the antidiabetic activity. A study against streptozotocin reported protective properties of jambu semarang fruit extract (STZ)-induced pancreatic $\beta$-cell apoptosis in diabetic rats for 30 days. The results were an alleviation of pancreatic $\beta$-cell apoptosis with significant expression of upregulated $\mathrm{Bcl} 2$ and $\mathrm{Bcl}$-xl protein, also down-regulated cleaved caspase- 3 and Bax protein expression. The extract also improved pancreatic $B$-cell function, possibly caused by inhibiting oxidative stress and pro-inflammatory cytokine also activating anti-apoptotic proteins [46]. Water-soluble polysaccharide fraction (WAFP) isolated from fruit exhibited an effective inhibitory effect on $\alpha$-glucosidase activity [19].

Fruit extract was also known to enhance the glucose uptake ability of insulin-resistant FL83B rat hepatocytes. A recent study evaluated the hypotriglyceridemic and hypoglycemic effect of fruit extract in a high-fructose diet (HFD)-induced diabetic Wistar rats. Vescalagin, which was administered $30 \mathrm{mg} / \mathrm{kg}$ body weight for a 4 weeks period, demonstrated a respectively decrease in the number of fasting blood glucose $(44.7 \%)$, c-peptide $(46.2 \%)$, fructosamine $(4 \%)$, triglyceride $(42.5 \%)$, and free fatty acid $(10 \%)$ contents. Also, it be mentioned that there was an increase of high-density lipoprotein-cholesterol content by $14.4 \%$ [41]. 
A different study was also conducted using FL83B mouse hepatocytes, where the fruit fraction of jambu semarang was evaluated to enhance glucose uptake in TNF- $\alpha$-induced insulin resistant Wistar rats. Fruit fraction increased expression of insulin receptor (IR), insulin receptor substrate-1 (IRS-1), protein kinase B (Akt/PKB), phosphatidylinositol-3 kinase (PI3K), and glucose transporter 2 (GLUT-2), and IR tyrosyl phosphorylation. The same cell also decreased phosphorylation of c-Jun N-terminal kinases (JNK), but not the expression of the intercellular signal-regulated kinases (ERK). There was an alleviation of insulin resistance in TNF- $\alpha$-treated FL83B cells by activating PI3K-Akt/PKB signaling and inhibited inflammatory response via suppression of JNK cascade activation [45].

The antidiabetic activity was determined at jambu semarang roots extracted by ethyl acetate, methanol, and water solvents by continuous extraction in the Soxhlet apparatus. The results stated that water extract showed the highest percentage of $\alpha$-amylase inhibitory, followed by methanol and ethyl acetate extract [3].

Resorcinol derivatives with long aliphatic chains were isolated from jambu semarang leaves. There are nine resorcinol derivatives that have been reported before, demonstrating a significant inhibitory effect towards $\alpha$-glucosidase as a promising antidiabetic alternative with IC50 value 3.16, 3.16, 2.34, and $0.99 \mathrm{mM}$, respectively [25].

Further study needs to be conducted to develop the potential drug or food supplement against diabetes.

\subsubsection{Thrombolytic and spasmolytic activity.}

Methanolic extract of jambu semarang leaves had effectively show a thrombolytic activity by its significant clot lysis activity $(32.73 \pm 2.57 \%)$ compared to streptokinase drug positive control $(75.00 \pm 2.60 \%)$ and distilled water as a negative control $(5.55 \pm 1.20 \%)$ [47]

In vivo spasmolytic activity study showed that n-hexane extract of jambu semarang relaxed the contracting isolated rabbit jejunum. Flavonoids that were isolated from this extract: 2'-hydroxy-4',6'-dihydroxy-3'-methylchalcone, 2',4'-dihydroxy-6'-methoxy-3',5'-dimethyl chalcone, 2',4'-dihydroxy-6'-methoxy-3'-methylchalcone, and 7-hydroxy-5-methoxy-6,8dimethyl-flavanone. The most potent compound (2',4'-dihydroxy-6'-methoxy-3', ''dimethylchalcone) was reported in a dose-dependent study $(10-100 \mathrm{mg} / \mathrm{ml})$ with spasmolytic activity was [8].

\subsubsection{Cytotoxic activity.}

Ethanolic extract of jambu semarang leaves showed a cytotoxicity activity towards human breast cancer (HeLa) cells. Viable cancer cells were incubated with different extract concentrations and demonstrated a dose-dependent pattern effect with an $\mathrm{IC}_{50}$ value of 40.5 $\mathrm{mg} / \mathrm{ml}$. Preliminary screening found that fatty acids, alkaloids, flavonoids, terpenoids, saponins, tannins, and steroids of $S$. samarangense extract are responsible for the cytotoxicity activity[17]. Cytotoxic activities were also examined from this extract against two other tumor cell lines, HepG2 and MDA-MB-231 cells, which displayed potent cytotoxic activities ranging from 1.73 to $32.90 \mu \mathrm{M}$ and 4.02 to $37.83 \mu \mathrm{M}$, respectively [23].

\subsubsection{Hepatoprotective activity.}

Methanolic leaves extract had a hepatoprotective activity in carbon tetrachloride $\left(\mathrm{CCl}_{4}\right)$-treated rats. Carbon tetrachloride induces severe hepatic toxicity because of its 
metabolism by cytochrome P450s in the liver into halogenated free radicals. These metabolites destruct the hepatic tissue and result in serious lipid peroxidation. It also attributes to covalent bonds with membrane lipids formation. This extract was reported to increase the reduced glutathione by $84.75 \%$ and superoxide dismutase activities by $26 / 27 \%$ and decrease in total bilirubin $37 \%$, total cholesterol $13.26 \%$, and total cholesterol glycerides by $15.15 \%$. Histopathological analyses also confirmed this report [48].

S. samarangense fruits were also reported to have a hepatoprotective activity towards alcohol-induced liver injury mice. Alcohol chronic treatment increased the level of aspartate transaminase (AST), alanine transaminase (ALT), total bilirubin (TB), triglyceride (TG), malondialdehyde (MDA), also respectively decreased the total protein (TP). The fruit extract normalized these biochemical markers [49].

\subsubsection{Anticancer activity.}

An anti-colon cancer activity of $S$. samarangense pulp in methanol extract was examined on SW-480 human colon cancer cell line using MTT (3-(4,5- dimethylthiazol-2-yl)2-5-diphenyltetrazolium bromide) assay with epigallocatechin gallate as a positive control. The results showed high toxicity towards cancer cell, and further toxicity study yet to be conducted [50].

Another study expressed that dimethyl cardamon isolated from the leaves could inhibit HCT 116 and LOVO human colorectal carcinoma cell proliferation and induce $\mathrm{G}_{2} / \mathrm{M}$ cell cycle arrest. The effects attributed to the induction of autophagy respectively [51].

Castalagin and vestalagin isolated from the leaves of $S$. samarangense demonstrated dual in vitro inhibitory activity towards PARP1 and DNA topoisomerase II (Top2) of SHSY5Y cells. These compounds attenuated cellular PARP1 activity with $\mathrm{IC}_{50}$ values at $0.86 \mu \mathrm{M}$ and $2.67 \mu \mathrm{M}$ for castalagin and vestalagin, respectively, without any sign of cell death characterized by the emergence of floating or changing shape of the cell. Analysis of castalagin and vestalagin structures described that different $\mathrm{OH}$-orientation affected this difference inhibition activity. Top2 had a big role in cancer chemotherapy development due to its DNA topological changes that required DNA replication, transcription, and chromosomal segregation alongside topoisomerase I (Top1). Castalagin and vestalagin significantly suppressed Top2-dependent conversion from supercoiled DNA to various relaxation degrees [51].

\subsubsection{Anthelmintic activity.}

The anthelmintic study was normally investigated base on the paralysis and death rate effect of living parasites. Polyphenolic compounds played a major role in these studies, especially tannins. Tannins facilitate energy depletion in helminths by performing uncoupling oxidative phosphorylation. Methanolic extract of jambu semarang leaves revealed a comparable effect with albendazole in an animal model. Ethanolic extract of barks also demonstrated anthelmintic activity compared with the standard anthelmintic drug albendazole. Both studies evaluated the extract in 25, 50,100, and $200 \mathrm{mg} / \mathrm{ml}$. Time estimation of these two studies reported a quicker paralysis and death effect on a higher extract concentration. The vermicidal activity of methanolic leaves extract was measured by their effect on paralysis and death of anthelmintics parasite at $200 \mathrm{mg} / \mathrm{dl}$ [47]. In vitro evaluation resulted in a dose- 
dependent manner and a significant effect statistically [7]. The mechanism action of the extract needs to be studied later.

\subsubsection{Anxiolytic activity.}

Anxiolytic activity of $S$. samarangense methanol extract measured using a light and dark box test (LDB) at doses 200 and $400 \mathrm{mg} / \mathrm{kg}$ body weight. The extract showed an increasing number of animal model crossing movement and time spend in either light or dark box $29.67 \pm 2.71$ and $230.80 \pm 16.39$ second compared to diazepam $28.50 \pm 2.31$ and 254.00 \pm 7.34 second, as the standard. The anxiolytic activity was also measured by elevated plus maze (EPM). The test showed that this extract increased the percentage of entries and duration needed into the open arm compared to the negative control group. Statistically, this study also displays a significant effect in a dose-dependent manner [47].

\subsubsection{Protease inhibitory activity.}

$\mathrm{N}$-hexane extract of $S$. samarangense leaves exhibited inhibitory activity towards serine proteases, such as trypsin, thrombin, and prolyl endopeptidase (PEP). Lupeol, betulin, epibetulinic acid, 2',4'-dihydroxy-6'-methoxy-3'-methylchalcone, 2'-hydroxy-4',6'dimethoxy-3'-methylchalcone, 2'-4'-dihydroxy-6'-methoxy-3',5'-dimethylchalcone, and 7hydroxy-5-methoxy-6,8-dimethylflavanone responsible for significant PEP inhibition. PEP has a role in several neuropeptides degradation, such as vasopressin, substance $\mathrm{P}$, and thyrotropinreleasing hormone (TRH), involved in the learning and memory process. PEP inhibition improved memory by blocking the endogenous neuropeptides metabolism. This inhibition might be a potential target for antidementia drug development[8].

Volatile oils of leaves inhibited the purified extracellular protease enzyme of Salmonella typhimurium. Inhibition was observed from the enzyme-substrate kinetic method using a line-weaver burke plot [37]. Another study demonstrated that the same method resulted in the same inhibition activity of volatile oils towards purified Escherichia coli. This volatile oils inhibited with IC50 value of $0.42 \%$ (v/v) [38]. Further isolation and identification of these bactericidal-specific volatile oil constituents would be impactful towards antimicrobial chemotherapy development.

\subsubsection{Immunomodulatory activity.}

Sixteen flavonoids were isolated from acetone extract of $S$. samarangense. Four of them described an inhibitory potency on human peripheral blood mononuclear cells (PBMC) proliferation activated by phytohemagglutinin (PHA). Those flavonoids, (-)-strobopinin, myricetin 3-O-(2'-O-galloyl)-a-rhamnopyranoside, (-)-epigallocatechin 3-O-gallate, and myricetin 3-O-a-rhamnopyranoside, were reported to reduce IL-2. The inhibitory mechanism involved by IL-2 blockage and Interferon-g (IFN-g) production in a dose-dependent manner [8].

\subsection{Toxicity study.}

With its no toxicity events until the dose of $1000 \mathrm{mg} / \mathrm{kg}$ toxicity test toward albino Swiss mice, methanolic extract of $S$. samarangense leaves was reported to be safe [40]. Another study upon the administration of dichloromethane extract of the leaves containing mainly 
cycloartenyl stearate, lupenyl stearate, sitosteryl stearate, and 24-methylenecycloartanyl stearate also reported no toxicity event. Toxicity examination with dechorionated embryos of zebrafish showed no mortality and teratogenicity effect. There was no necessary abnormality of all treatments. There was a delay in the hatching of embryos with intact chorion treated with extract. Hence there was no toxicity compared to diclofenac as a positive control [28]. Taken together, these results underline the safety of $S$. samarangense at the preclinical level. Further safety evaluation at the clinical level yet to be done.

\subsection{Further development of S. samarangense.}

Research on pharmacological activities of $S$. samarangense contributed to the development of the natural produce of the plant. A in silico study showed a promising docking score, glide model, and glide energy of jambu semarang isolate obtained from SwissADME database, where the docking value would give a potential novel drug [47].

Cell viability of hot water leaves and twigs extract of $S$. samarangense measured by MTT assay in human keratinocyte cells ( $\mathrm{HaCaT})$. The cell viability of these extracts was lowered due to their low stimulation level. The test observed that a slight irritation appeared. The lower concentration should be evaluated to have more comprehensive data on this irritation. This study showed a possible candidate for topical application [35]. Effective formulation by concentration and excipient adjustment needs to be done for further development.

The pharmaceutical formulation had been conducted from S. samarangense fruit extracts as an anti-acne cream. This formulated cream showed antibacterial activity, including acne vulgaris. The evaluation of this formula reported stability for two months duration. Further clinical and toxicological studies were recommended to develop this product into commercial standards [52].

Besides pharmaceutical usage, the study of $S$. samarangense was also conducted from lots of perspectives. Other studies of this plant focused on developing this extract as a DNA fingerprint [53], bio-semiconductor [54], and other studies.

Modernized natural product development gives a bigger picture of what challenges might be seen towards future novel drug development. Isolation, standardization, and quality control will focus on developing medicine that meets the safety, quality, and efficacy requirements [47]. Harmonization and modernization of scientific research need to be done in a multidisciplinary field [1].

\section{Conclusions}

S. samarangense produces diverse metabolites, including flavonoids, phenolic compounds, resorcinol derivatives, acylphloroglucinols, tannins, terpenoids, sterols, and other metabolite groups. Past studies of this plant extract showed various pharmacology activities by in vivo and in vitro experiments. Negligible toxicity was reported. Other development was also exhibited an in-silico assay, topical formulation assay, and other biological studies. Modern challenges of this natural product development will be focused on isolation, standardization, and quality control to develop a novel medicine that meets the safety, quality, and efficacy requirements. Multidisciplinary scientific research needs to be done for further drug development and discovery. 


\section{Funding}

This research received no external funding.

\section{Acknowledgments}

The authors wish to respect the facilities support of the Department of Pharmaceutical Biology, School of Pharmacy, Bandung Institute of Technology, Indonesia.

\section{Conflicts of Interest}

The authors declare no conflict of interest.

\section{References}

1. Veeresham, C. Natural products derived from plants as a source of drugs. J Adv Pharm Technol Res 2012, 3, 200-201, https://doi.org/10.4103/2231-4040.104709.

2. Rehman, M.U.; Abdullah; Khan, F.; Niaz, K. Introduction to natural products analysis. In Recent advances in natural products analysis; Elsevier, 2020; 3-15.

3. Aung, E.E.; Kristanti, A.N.; Aminah, N.S.; Takaya, Y.; Ramadhan, R. Plant description, phytochemical constituents and bioactivities of Syzygium genus: A review. Open Chem 2020, 18, 1256-1281, https://doi.org/10.1515/chem-2020-0175.

4. Ahmad, B.; Baider, C.; Bernardini, B.; Biffin, E.; Brambach, F.; Burslem, D.; Byng, J.W.; Christenhusz, M.J.M.; Florens, F.B.V. Syzygium (Myrtaceae): Monographing a Taxonomic Giant via 22 Coordinated Regional Revisions. PeerJ Preprints 2016, https://doi.org/10.7287/peerj.preprints.1930v1.

5. Soh, W.-K.; Parnell, J. A Revision of Syzygium Gaertn. (Myrtaceae) in Indochina (Cambodia, Laos and Vietnam). Adansonia 2015, 37, 179-275, https://doi.org/10.5252/a2015n2a1.

6. Al-Obaidi, J.R.; Jamil, N.A.M.; Rahmad, N.; Rosli, N.H.M. Proteomic and metabolomic study of wax apple (Syzygium samarangense) fruit during ripening process. Electrophoresis 2018, 39, 2954-2964, https://doi.org/10.1002/elps.201800185.

7. Gayen, P.R.; Hossain, A.M.A.; Saifuzzaman, M.; Faroque, A. Anthelmintic activity of ethanolic extract of Syzygium samarangense (Blume) Merril \& Perry. Dhaka Univ J Pharm Sci 2016, 15, 109-111, https://doi.org/10.3329/dujps.v15i1.29204.

8. Lim, T.K. Syzygium samarangense. In Edible medicinal aand nonmedicinal plants; Springer Netherlands: Dordrecht, 2012; 778-786.

9. Khandaker, M.M.; Boyce, A.N. Growth, distribution and physiochemical properties of wax apple (Syzygium samarangense): A review. Aust $J$ Crop Sci 2016, 10, 1640-1648, https://doi.org/10.21475/ajcs.2016.10.12.PNE306.

10. Setiani, B.E.; Pramono, Y.B.; Darmawan, B.R. The characteristics of nata-de guava (Syzygium samarangense) with certain interaction on the proportion of sprout extract (Phaseolus vulgaris) and sucrose. IOP Conf Ser: Earth Environ Sci 2019, 292, 012045, https://doi.org/10.1088/1755-1315/292/1/012045.

11. Mukaromah, A.S. Wax apple (Syzygium samarangense (Blume) Merr. \& L.M. Perry): A comprehensive review in phytochemical and physiological perspectives. $A H$ 2020, 3, 40-58, https://doi.org/10.21580/ah.v3i1.6070.

12. Shü, Z.-H.; Shiesh, C.-C.; Lin, H.-L. Wax apple (Syzygium samarangense (Blume) Merr. and L.M. Perry) and related species. In Post-harvest biology and technology of tropical and subtropical fruits; Elsevier, 2011; $458-475$.

13. Nguyen, K.; Tran, G.; Van, H. Comparison of five wax apples (Syzygium samarangense) from Dong Thap Province, Vietnam based on morphological and molecular data. Banats $J$ Biotechol 2020, 11, 50-57, https://doi.org/10.7904/2068-4738-XI(21)-50.

14. Lu, P.-L.; Lin, C.-H. Physiology of fruit cracking in wax apple (Syzygium samarangense). Bot Or 2012, 8, 70-76, https://doi.org/10.3126/botor.v8i0.5954. 
15. Chen, Y.; Zhang, Y.; Nawaz, G.; Zhao, C.; Li, Y.; Dong, T.; Zhu, M.; Du, X.; Zhang, L.; Li, Z.; Xu, T. Exogenous melatonin attenuates post-harvest decay by increasing antioxidant activity in wax apple (Syzygium samarangense). Front Plant Sci 2020, 11, 569779, https://doi.org/10.3389/fpls.2020.569779.

16. Liu, J.; Ni, S.-B.; Zheng, C.; Shi, C.; Niu, Y.-F. Chloroplast genome of tropical and sub-tropical fruit tree Syzygium samarangense (Myrtaceae). Mitochondrial DNA Part B 2018, 3, 890-891, https://doi.org/10.1080/23802359.2018.1501296.

17. Poonkodi, K.; Mini, R.; Vimaladevi, K.; Prabhu, V.; Anusuya, M.; Karthigaipriya, M.; Saranya, K.S. In vitro cytotoxicity potential of ethanol extract of Syzygium samarangense (Wt.). Kong Res J 2019, 6, 30-32, https://doi.org/10.26524/krj283.

18. Khandaker, M.M.; Nasrulhaq Boyce, A.; Osman, N.; Sharif Hossain, A. Physiochemical and phytochemical properties of wax apple (Syzygium samarangense [Blume] Merrill \& L. M. Perry var. Jambu Madu) as affected by growth regulator application. Sci World J 2012, 2012, 1-13, https://doi.org10.1100/2012/728613.

19. Wang, B.-H.; Cao, J.-J.; Zhang, B.; Chen, H.-Q. Structural characterization, physicochemical properties and $\beta$-glucosidase inhibitory activity of polysaccharide from the fruits of wax apple. Carbohydr Polym 2019, https://doi.org/10.1016/j.carbpol.2019.02.006.

20. Budiono, B.; Elfita, E.; Muharni, M.; Yohandini, H.; Widjajanti, H. Antioxidant activity of Syzygium samarangense L. and their endophytic fungi. Molekul 2019, 14, 48-55, https://doi.org/10.20884/1.jm.2019.14.1.503.

21. Hu, Y.-K.; Wang, L.; Li, Y.-Y.; Li, M.-J.; Xu, W.; Zhao, Y.; Li, F.; Zhao, Y. Five new triterpenoids from Syzygium samarangense (B1.) Merr. et Perry. Phytochem Lett 2018, 25, 147-151, https://doi.org./10.1016/j.phytol.2018.04.018.

22. Hu, Y.-K.; Wang, L.; Zhao, Y.; Liu, J.-P.; Wang, J.-H.; Zhao, Y. Two new oleanane triterpenoids from Syzygium samarangense. Chem Nat Compd 2020, 56, 692-695, https://doi.org/10.1007/s10600-020-03121$\mathrm{z}$.

23. Yang, J.; Su, J.-C.; Lei, X.-P.; Huang, X.-J.; Zhang, D.-M.; Ye, W.-C.; Wang, Y. Acylphloroglucinol derivatives from the leaves of Syzygium samarangense and their cytotoxic activities. Fitoterapia 2018, 129, 1-6, https://doi.org/10.1016/j.fitote.2018.06.002.

24. Sobeh, M.; Braun, M.S.; Krstin, S.; Youssef, F.S.; Ashour, M.L.; Wink, M. Chemical profiling of the essential oils of Syzygium aqueum, Syzygium samarangense and Eugenia uniflora and their discrimination using chemometric analysis. Chem Biodiversity 2016, 13, 1537-1550, https://doi.org/10.1002/cbdv.201600089.

25. Hu, Y.-K.; Wang, L.; Wang, J.-H.; Li, M.-J.; Li, F.; Yang, J.; Zhao, Y. Resorcinol derivatives with $\alpha-$ glucosidase inhibitory activities from Syzygium samarangense. Nat Prod Res 2020, 1-6, https://doi.org/10.1080/14786419.2020.1805606.

26. Kim, Y.-J.; Kim, H.-C.; Ko, H.; Amor, E.C.; Lee, J.W.; Yang, H.O. Inhibitory effects of aurentiacin from Syzygium samarangense on lipopolysaccharide-induced inflammatory response in mouse macrophages. Food Chem Toxicol 2012, 50, 1027-1035, https://doi.org/10.1016/j.fct.2011.11.050.

27. Jugreet, B.S.; Mahomoodally, M.F. Essential oils from 9 exotic and endemic medicinal plants from Mauritius shows in vitro antibacterial and antibiotic potentiating activities. S Afr J Bot 2020, 132, 355-362, https://doi.org/10.1016/j.sajb.2020.05.001.

28. Raga, D.D.; Cheng, C.L.C.; Olaziman, W.Z.P.; Jr, F.C.F.; Ragasa, C.Y. Bioactivities of triterpenes and a sterol from Syzygium samarangense. Z Naturforsch 2011, 66, 235-244, https://doi.org/10.1515/znc-2011-5606.

29. Ragasa, C.Y.; Torres, O.B.; Shen, C.-C.; Lachica, M.K.E.G.; Sulit, A.B.; Chua, D.B.D.L.; Ancheta, A.D.M.; Ismail, C.J.B.; Bernaldez, F.T.E.; Raga, D.D. Triterpenes from the leaves of Syzygium polycephalum, S. cumini, and S. samarangense. Chem Nat Compd 2014, 50, 942-944, https://doi.org/10.1007/s10600-0141126-2.

30. Mamdouh, N.S.; Sugimoto, S.; Matsunami, K.; Otsuka, H.; Kamel, M.S. Taxiphyllin 6'-O-gallate, actinidioionoside 6'-O-gallate and myricetrin 2"-O-sulfate from the leaves of Syzygium samarangense and their biological activities. Chem Pharm Bull 2014, 62, 1013-1018, https://doi.org/10.1248/cpb.c14-00352.

31. Sobeh, M.; Petruk, G.; Osman, S.; El Raey, M.A.; Imbimbo, P.; Monti, D.M.; Wink, M. Isolation of Myricitrin and 3,5-di-O-methyl gossypetin from Syzygium samarangense and evaluation of their involvement in protecting keratinocytes against oxidative stress via activation of the Nrf-2 pathway. Molecules 2019, 24, 1839, https://doi.org/10.3390/molecules24091839. 
32. Shahreen, S.; Banik, J.; Hafiz, A.; Rahman, S.; Zaman, A.; Shoyeb, A.; Chowdhury, M.; Rahmatullah, M. Antihyperglycemic activities of leaves of three edible fruit plants (Averrhoa carambola, Ficus hispida and Syzygium samarangense) of Bangladesh. Afr J Trad Compl Alt Med 2012, 9, 287-291, https://doi.org/10.4314/ajtcam.v9i2.16.

33. Shu, C.-Y.; Shelomi, M. Syzygium samarangense leaf infusion as Aedes albopictus (Diptera: Culicidae) ovitrap bait. J Med Entomol 2020, 20, 1-4, https://doi.org/10.1093/jme/tjaa231.

34. Khandaker, M.M.; Osman, N.; Hossain, A.S.; Faruq, G.; Boyce, A.N. Effect of 2,4-D on growth, yield and quality of wax apple (Syzygium samarangense, (Blume) Merrill \& L.M. Perry cv. Jambu Madu) fruits. Sains Malays 2015, 44, 1431-1439, https://doi.org/10.17576/jsm-2015-4410-08.

35. Hyun, S.B.; Bae, S.; Hyun, C.-G. Antioxidant activities of jeju wax apple (Syzygium samarangense) and safety of human keratinocytes and primary skin irritation test. Cosmetics 2020, 7, 39, https://doi.org/10.3390/cosmetics7020039.

36. Amparo, T.R.; Vieira, P.M. de A.; Santos, O.D.H. dos. Herbal medicines to the treatment of skin and soft tissue infection: advantages of the multi-targets action. Phytother Res 2019, 34, 1-10, https://doi.org/10.1002/ptr.6519.

37. Folorunso, O.S.; Adeola, S.; Giwa Ajeni, A.O. Syzygium samarangense volatile oil inhibited bacteria growth and extracellular protease of Salmonella typhimurium. Pak J Biol Sci 2020, 23, 628-637, https://doi.org/10.3923/pjbs.2020.628.637.

38. Adesegun, S.A.; Samuel, O.F.; Anthony, B.O.; Folasade, B.O.; Mary, S.K. Essential oil of Syzygium samarangense; A potent antimicrobial and inhibitor of partially purified and characterized extracellular protease of Escherichia coli 25922. Br J Pharmacol Toxicol 2013, 4, 215-221, https://doi.org/10.19026/bjpt.4.5405.

39. Choironi, N.A.; Fareza, M.S. Phytochemical screening and antibacterial activity of ethanolic extract of Syzygium samarangense leaves. J. Kartika Kimia 2018, 1, 1, https://doi.org/10.26874/jkk.v1i1.2.

40. Mollika, S. Evaluation of analgesic, anti-inflammatory and CNS activities of the methanolic extract of Syzygium samarangense bark. iosrphr 2013,03, 12-18, https://doi.org/10.9790/3013-0311012-18.

41. Chang, W.-C.; Shen, S.-C.; Wu, J.S.-B. Protective effects of vescalagin from pink wax apple [Syzygium samarangense (Blume) Merrill and Perry] fruit against methylglyoxal-induced inflammation and carbohydrate metabolic disorder in rats. J Agric Food Chem 2013, 61, 7102-7109, https://doi.org/10.1021/jf4020284.

42. Shen, S.-C.; Chang, W.-C. Hypotriglyceridemic and hypoglycemic effects of vescalagin from Pink wax apple [Syzygium samarangense (Blume) Merrill and Perry cv. Pink] in high-fructose diet-induced diabetic rats. Food Chem 2013, 136, 858-863, https://doi.org/10.1016/j.foodchem.2012.08.037.

43. Shen, S.-C.; Chang, W.-C.; Chang, C.-L. An Extract from wax apple (Syzygium samarangense (Blume) Merrill and Perry) effects glycogenesis and glycolysis pathways in tumor necrosis factor- $\alpha$-treated FL83B mouse hepatocytes. Nutrients 2013, 5, 455-467, https://doi.org/10.3390/nu5020455.

44. Huang, D.-W.; Chang, W.-C.; Wu, J.S.-B.; Shih, R.-W.; Shen, S.-C. Vescalagin from pink wax apple [Syzygium samarangense (Blume) Merrill and Perry] alleviates hepatic insulin resistance and ameliorates glycemic metabolism abnormality in rats fed a high-fructose diet. J Agric Food Chem 2016, 64, 1122-1129, https://doi.org/10.1021/acs.jafc.5b05558.

45. Shen, S.-C.; Chang, W.-C.; Chang, C.-L. Fraction from wax apple [Syzygium samarangense (Blume) Merrill and Perry] fruit extract ameliorates insulin resistance via modulating insulin signaling and inflammation pathway in tumor necrosis factor $\alpha$-treated FL83B mouse hepatocytes. IJMS 2012, 13, 8562-8577, https://doi.org/10.3390/ijms13078562.

46. Khamchan, A.; Paseephol, T.; Hanchang, W. Protective effect of wax apple (Syzygium samarangense (Blume) Merr. \& L.M. Perry) against streptozotocin-induced pancreatic B-cell damage in diabetic rats. Biomedicine \& Pharmacotherapy 2018, 108, 634-645, https://doi.org/10.1016/j.biopha.2018.09.072.

47. Hossain, R.; Rahman, M.A.; Rafi, Md.K.J.; Siddique, T.A.; Noman, A.A.; Makki, A.; Alelwani, W.; Hajjar, D.; Tangpong, J. Pharmacological and ADMET-based pharmacokinetic properties of Syzygium samarangense var. parviflorum leaf extract in in vitro, in vivo and in silico models. Not Bot Horti Agrobo 2020, 48, 1155-1175, https://doi.org/10.15835/nbha48311986.

48. Sobeh, M.; Youssef, F.S.; Esmat, A.; Petruk, G.; El-Khatib, A.H.; Monti, D.M.; Ashour, M.L.; Wink, M. High resolution UPLC-MS/MS profiling of polyphenolics in the methanol extract of Syzygium samarangense leaves and its hepatoprotective activity in rats with CCl4-induced hepatic damage. Food Chem Toxicol 2018, 113, 145-153, https://doi.org/10.1016/j.fct.2018.01.031. 
49. Zhang, Y.-J.; Zhou, T.; Wang, F.; Zhou, Y.; Li, Y.; Zhang, J.-J.; Zheng, J.; Xu, D.-P.; Li, H.-B. The effects of Syzygium samarangense, Passiflora edulis and Solanum muricatum on alcohol-induced liver injury. Int $J$ Mol Sci 2016, 17, 1616-1627, https://doi.org/10.3390/ijms17101616.

50. Chua, L.K.; Lim, C.L.; Ling, A.P.K.; Chye, S.M.; Koh, R.Y. Anticancer Potential of Syzygium Species: A Review. Plant Foods Hum Nutr 2019, 74, 18-27, https://doi.org/10.1007/s11130-018-0704-z.

51. Kamada, Y.; Yakabu, H.; Ichiba, T.; Tamanaha, A.; Shimoji, M.; Kato, M.; Norimoto, C.; Yamashiro, R.; Miyagi, I.; Sakudo, A.; Tanaka, Y. Castalagin and vescalagin purified from leaves of Syzygium samarangense (Blume) Merrill \& L.M. Perry: Dual inhibitory activity against PARP1 and DNA topoisomerase II. Fitoterapia 2018, 129, 94-101, https://doi.org/10.1016/j.fitote.2018.06.015.

51. Sekar, M.; Halim, F. Formulation and evaluation of natural anti-acne cream containing Syzygium samarangense fruits extract. ARRB 2017, 17, 1-7, https://doi.org/10.9734/ARRB/2017/36467.

52. Lin, X.; Hu, X.; Wu, W.; Liu, S.; Li, C. Evaluation of the volatile profile of wax apple (Syzygium samarangense) wines fermented with different commercial Saccharomyces cerevisiae strains. Food Sci Biotechnol 2019, 28, 657-667, https://doi.org/10.1007/s10068-018-0511-1.

53. Moses, E.E.; Ikechukwu, M.A.; Okeniyi, E.A.; Olawepo, V.A.; Lyala, F.; Okeniyi, E.T.; Olademiji, T.E. Synthesis and characterization of zinc coated Syzygium samarangense extracts for solid-state application. Mater Today: Proc 2020, 1-5, https://doi.org/10.1016/j.matpr.2020.04.886. 